ORIGINAL ARTICLE / ARTIGO ORIGINAL

Reliability and validity of a physical activity social support assessment scale in adolescents - ASAFA Scale

\title{
Fidedignidade e validade de uma escala de avaliação do apoio social para prática de atividade física para adolescentes - Escala ASAFA
}

\author{
José Cazuza de Farias Júnior', Gerfeson Mendonça', Alex Antonio Florindo", \\ Mauro Virgilio Gomes de Barros ${ }^{\text {III }}$
}

\begin{abstract}
Objective: To analyze the reliability and validity of a scale used to measure social support for physical activity in adolescents - ASAFA Scale. Methods: This study included 2,755 adolescents ( $57.6 \%$ girls, $16.5 \pm 1.2$ years of age), from Joao Pessoa, Paraiba, Brazil. Initially, the scale was consisted of 12 items ( 6 for social support from parents and 6 from friends). The reliability of the scale was estimated by Cronbach's alpha coefficient $(\alpha)$, by the Composite Reliability (CR), and by the model with two factors and factorial invariance by Confirmatory Factor Analysis (CFA) adequacy. Results: The CFA results confirmed that the social support scale contained two factors (factor 1: social support from parents; factor 2: social support from friends) with five items each (one item was excluded from each scale), all with high factor loadings $(>0.65)$ and acceptable adjustment indexes $(\mathrm{RMR}=0.050$; RMSEA $=0.063 ; 90 \% \mathrm{CI}: 0.060-0.067)$; AGFI $=0.903 ; \mathrm{GFI}=0.940$; CFI $=$ 0.934 , NNFI $=0.932$ ). The internal consistency was satisfactory (parents: $\alpha \geq 0.77$ and $\mathrm{CR}^{3} \geq 0.83$; friends: $\alpha$ $\geq 0.87$ and $C R \geq 0.91$ ). The scale`s factorial invariance was confirmed ( $p>0.05 ; \Delta \chi^{2}$ and $\left.\Delta C F I \leq 0.01\right)$ across all subgroups analyzed (gender, age, economic class). The construct validity was evidenced by the significant association $(\mathrm{p}<0.05)$ between the adolescents physical activity level and the social support score of parents $($ rho $=0.29)$ and friends $($ rho $=0.39)$. Conclusions: The scale showed reliability, factorial invariance and satisfactory validity, so it can be used in studies with adolescents.
\end{abstract}

Keywords: Social support. Adolescent. Motor activity. Evaluation. Validity of tests. Reproducibility of results.

'Universidade Federal da Paraíba - João Pessoa (PB), Brazil.

"Escola de Artes, Ciências e Humanidades da Universidade de São Paulo - São Paulo (SP), Brazil.

"'Universidade de Pernambuco - Recife (PE), Brazil.

Corresponding author: José Cazuza de Farias Júnior. Centro de Ciência da Saúde do Departamento de Educação Física da Universidade Federal Paraíba, Cidade Universitária, CEP: 58059-900, João Pessoa, PB, Brazil. E-mail: jcazuzajr@hotmail.com

Conflict of interests: nothing to declare - Financial source: none. 
RESUMO: Objetivo: Analisar a fidedignidade e a validade de uma escala de apoio social para prática de atividade física para adolescentes - Escala ASAFA. Métodos: A amostra tinha 2.755 adolescentes (57,6\% do sexo feminino; idade 16,5 \pm 1,2 anos) do município de João Pessoa, Paraíba. Inicialmente a escala continha 12 itens: 6 para o apoio social dos pais e 6 para o dos amigos. A fidedignidade foi avaliada pelo alfa de Cronbach $(\alpha)$ e índice de fidedignidade combinada (IFC), a adequação do modelo com dois fatores e a invariância fatorial pela análise fatorial confirmatória (AFC). Resultados: A AFC confirmou a presença de dois fatores (fator 1: apoio social dos pais; fator 2: apoio social dos amigos), com cinco itens cada (foi excluído um item de cada escala), com cargas fatoriais elevadas $(>0,65)$ e índices de ajuste aceitáveis $[\mathrm{RMR}=0,050$; RMSEA $=0,063$; IC90\%: 0,060 - 0,067; AGFI =0,903; GFI =0,940; $\mathrm{CFI}=0,934, \mathrm{NNFI}=0,932$ ). A consistência interna foi satisfatória (pais: $\alpha \geq 0,77$ e IFC $\geq 0,83$; amigos: $\alpha \geq 0,87$ e IFC $\geq 0,91$ ). A invariância fatorial da escala foi confirmada ( $p>0,05$ para $\Delta \chi 2$ e $\Delta C F I \leq 0,01$ ) em todos subgrupos analisados (sexo, idade, classe econômica). A validade de construto foi constatada pela associação significativa $(\mathrm{p}<0,05)$ entre o nível de atividade física e o escore de apoio social dos pais ( $\mathrm{rho}=0,29)$ e dos amigos $(\mathrm{rho}=0,39)$. Conclusões: A escala analisada alcançou fidedignidade, invariância fatorial e validade satisfatórias, recomendando sua utilização em adolescentes.

Palavras-chave: Apoio social. Adolescente. Atividade motora. Avaliação. Validade dos testes. Reprodutibilidade dos testes.

\section{INTRODUCTION}

A high prevalence of physical inactivity among adolescents is widely described. It is estimated that around 8 in 10 adolescents are physically inactive ${ }^{1}$. Low levels of physical activity are associated with a series of health problems, such as obesity, high blood pressure and risk factors for metabolic syndrome ${ }^{2}$. Furthermore physical activity habits adopted during teenage years predict some of the physical activity's levels in adulthood ${ }^{3}$.

In this respect, increasing physical activity's levels among adolescents has been considered as a priority to public health ${ }^{4}$. Adolescents' physical activity practices influence factors that have been considered essential for the development of programs to increase physical activity's levels in this people group 5 . Among these factors (such as self-efficacy, social support, physical environment), social support has emerged as one of the most importantes ${ }^{6}$.

Social support is described as the assistance offered or as the resources made available by different groups, such as parents, siblings, relatives, friends and others, in situations of need, and it can be measured with individual perception of the degree 
to which interpersonal relationships correspond to certain functions (instrumental social support/direct, psychological/emotional, instrumental/informational $)^{6}$.

In the physical activity's context social support is one of the main constructs for theories and models that are used (e.g., Sociocognitive theory, Socioecological models) in factors associated with this behavior's studies ${ }^{6}$. Social support is consistently associated with higher levels of physical activity practices in adolescents ${ }^{4}$, and they may occur through incentives, joint practice, providing transportation and assistance, as parents and friends are the main sources of support ${ }^{7}$.

There are several instruments to measure social support for adolescents' physical activity practices available in the literature. Some consider social support from different social groups simultaneously ${ }^{8}$, others measure the support from parents, from friends ${ }^{9}$ and there are those that measure the social support of two or more groups, but with specific items for each one ${ }^{10,11}$. These instruments also show variations in the kind of social support measured ${ }^{7,12-14}$.

The different sources and types of social support influence the adolescents' participation in different physical activities in their specific way ${ }^{7,12}$. For example, the social support provided by parents associated with physical activity is through facilitating access to sports equipment and practice places, transportation to practice places and incentives for their children to perform physical activities ${ }^{15}$. As for friends, joint participation in physical activities practices and incentives to practice are associated with adolescents' greater involvement in physical activities ${ }^{7,12,14,16}$. This reinforces the importance of taking in consideration the main sources and the different kinds of social support for physical activity when assessing this construct.

Studies on social support and physical activity levels have been developed primarily with adolescents in the United States and some European countries ${ }^{4,17}$. Due to socio-cultural and environmental differences, the available and used tools in these studies have applications restrictions in Brazilian adolescents. It is also necessary to take in consideration that most of these studies went through reliability analysis ${ }^{4,17}$, what put them in a position of not representing a sufficient condition to express validity ${ }^{18}$. With this, Farias Junior et al. ${ }^{19}$ developed and analyzed the reliability and factor structure of a social support for physical activity among adolescents`scale-ASAFA Scale. This scale considers the different kinds and the main sources of social support for physical activity, and was developed from items taken from other scales used in adolescents. Exploratory factor analysis of this scale revealed the presence of two factors (social support from parents and from friends, six items for each), with internal consistency $(\alpha 0.81-0.90)$ and test-retest reproducibility (intraclass correlation coefficient [ICC] 0.89 - 0.91) satisfactory. However, confirmatory factor analysis, factorial invariance and construct validity of the ASAFA Scale have not yet been established.

Confirmatory Factor Analysis (CFA) has been considered as the most appropriate analysis to strongly test the scales` factor structure ${ }^{20}$. Construct validity refers to the relationship between the construct allegedly picked up by the instrument that you want 
to evaluate with related attributes or features to the construct under study, according to previous and literature supported hypotheses ${ }^{18}$. A scale's factorial invariance represents the level at which factor structure, factor loadings, variances, covariances and measurement errors of their items are similar among subjects with different features ${ }^{21}$. The factorial invariance is a necessary condition to establish comparison of different groups in relation to the results of a variable ${ }^{22}$. In the absence of factorial invariance, possible differences between subgroups or populations for a given variable can be attributed to variations in the instrument's psychometric properties over the actual variations in the results ${ }^{21}$. Differences in physical activity levels and in social support among adolescents with different sociodemographic characteristics are widely documented in the literature $\mathrm{e}^{8-14}$. Therefore, it is necessary to evaluate possible changes in psychometric properties of the ASAFA Scale regarding these characteristics. This study examined the reliability, factorial invariance and validity of a social support for physical activity practices in adolescents in northeastern Brazil scale.

\section{METHODOLOGY}

Study inserted into a larger research entitled "Physical activity levels and factors among high school students in the city of Joao Pessoa, Paraiba: an ecological approach”, approved by the Comite de Etica em Pesquisa com Seres Humanos da Universidade Federal da Paraiba (0062 / 09) and held in 2009. All adolescents $<18$ years old were allowed by their parents or guardians to participate in the study.

The sample selection was a two-stage group choice. In the first stage 30 schools were systematically selected, proportionally distributed by type (public or private), city area (north, south, east and west) and school size (enrolled students' number). In the second stage 135 high school classes were randomly selected, distributed proportionally by high school year $\left(9^{\text {th }}, 10^{\text {th }}\right.$ and $11^{\text {th }}$ grades) and shift (day [morning + afternoon] and evening). Detailed information about the sampling process were described in a previous publication $^{23}$.

Data collection occurred in 2009 between the months of May and September, and it was performed by six previously trained Physical Education students that received a manual with the protocol for data collection in the study. The questionnaire was completed by the adolescents themselves in the classroom, following previous staff's instructions for data collection.

There were 3,477 students selected to participate in the study, though 70 were not allowed by their parents or guardians or refused to participate and 187 were not found in at least three research team visits. Of the 3,220 adolescents who completed the questionnaire, 361 were excluded ( 271 were $<14$ or $>19$ years of age, 65 did not state their age, 15 did not report the sex, five returned with several unanswered questions 
and five had some limitation of physical order or mental). Data from 2,859 adolescents aged 14 to 19 years old and of both sexes were obtained.

The following variables were used to characterize the sample: sex, age and socio-economic status. The economic class determination followed the proposal of the Associação Brasileira de Empresas de Pesquisa (ABEP) ${ }^{24}$, that gathers people into classes A1, A2 (best condition), $\mathrm{B} 1, \mathrm{~B} 2, \mathrm{C} 1, \mathrm{C} 2$, D and $\mathrm{E}$ (worst condition).

The social support for physical activity practices among adolescents scale - ASAFA Scale - was drawn from the compilation of items from other scales applied in adolescents ${ }^{19}$. The scale's initial version contained 12 items, including 6 for parents' social support and 6 friends' social support, considering different types of support (to stimulate, to practice, to watch, to ask, to comment and to carry or provide transportation). All items are anchored in the four-points Likert Scale and asked the frequency (never $=0$, rarely $=1$, often $=2$, always $=3$ ) that parents and friends offered each kind of social support in a typical week. More information were previously described ${ }^{19}$.

CFA was used in order to assess the model's goodness of fit in two dimensions or factors - social support from parents and social support from friends - and to compare the competing models. For that the structural equation modeling, using the Analysis of Moment Structures (AMOS) 20.0 program, was used by resorting to the maximum likelihood method ${ }^{20}$.

The data's multivariate normality was verified by Mardia's index, whose standardized value must be less than five to characterize multivariate normal distribution. This was verified in this study (Mardia $=4.73$; critical value $=1.93$ ). The model's goodness of fit evaluation was performed using different fix indexes because each one reflects its one specific aspect ${ }^{22}$. In the present study, the indexes used and their values considered acceptable were: Chi-squared $\left(\chi^{2}\right)$, Root Mean Square Residual (RMR) $(<0.05$, are tolerated values up to 0.08), Root Mean Square of Approximation (RMSEA) $(\leq 0.05$, are tolerated values up to $<0.10)$, Goodness of Fit Index (GFI) $(\geq 0.90)$, Adjusted Goodness of Fit Index (AGFI) ( $\geq 0.90$ ), Comparative Fit Index (CFI) ( $\geq 0.90)$, Nonnormed Fit Index (NNFI) $(\geq 0.90)^{20}$.

In the initial model, it was considered that the social support for physical activity practices scale had two factors with six items each, for this configuration had already been identified in the exploratory factor analysis ${ }^{19}$ : (1) parents' social support; (2) friends' social support. The changes in the model (respecification) were made from the Modification Index (MI) and the residuals values. The modification indices indicate the statistical $\chi^{2}$ values expected changes, if certain set parameter was estimated freely. There is no reference value for this indicator, and the decision to produce changes in the model have to be based on evidence and theoretical basis ${ }^{22}$. Regarding the values of the standardized residuals, it is recommended that they stay around $\pm 2.58^{20}$. The CFA was repeated after each modification to evaluate possible changes in the model's goodness of $\mathrm{fit}^{22}$. The adjustments changes evaluation was performed with the Akaike Information Criterion (AIC) and the Expected Cross-Validation Index (ECVI). AIC and ECVI values 
reduction indicate adjustments improvements ${ }^{22}$. The following parameters were also considered: RMR, RMSEA (90\%CI), GFI, AGFI, CFI, NNFI ${ }^{20,22}$.

It was analyzed the reliability of the social support scale by determining the internal consistency, resorting to Cronbach's alpha coefficient $(\alpha)$ and the Composite Reliability $\mathrm{CR}=[\Sigma \text { factor loadings }]^{2} /[\Sigma \text { factor loadings }]^{2+} \sum\left[1\right.$ - factor loadings $\left.{ }^{2}\right]$. The $\alpha$ values can be underestimated in scales with two or more factors ${ }^{25}$. The $\alpha$ and the CR values were considered satisfactory when equals or superior to $0.70^{25}$.

The scale's factorial invariance was analyzed by testing and comparing a number of models, adopting a set of standardized procedures. The first step was to define the model's fit for each subgroup separately (male versus female; $14-16$ versus 17 19 years of age; socioeconomic class A/B versus C/D/E) ${ }^{22}$. After that, this model was subjected to a multigroups analysis, resorting to the option "Emulisrel6 Method" from the AMOS 20.0 program, settling the factor loadings, variance and covariance, and measurement error, as recommended in the literature ${ }^{22}$. Model 1 tested the hypothesized structural model proposed equivalence, without imposing restrictions. This model served as a comparison basis for the more restrictive models that will be following introduced. In model 2 , the restriction was imposed on the items' factor loadings to assess whether the factor structure is similar among the analyzed subgroups. In model 3, the variances and covariances, and in model 4, the items measurement errors variance. The difference value of $\chi^{2}\left(\Delta \chi^{2}\right)$ and its degrees of freedom ( $\left.\Delta \mathrm{df}\right)$ and the CFI values differences $(\triangle \mathrm{CFI})$ were used to analyze the models (M1 versus M2 M4) differences. Values of $\mathrm{p}>0.05$ for $\Delta \chi^{2}$ and $\Delta \mathrm{CFI} \leq 0.01$ were the criteria to define factorial invariance ${ }^{20-22}$. The Spearman's correlation coefficient between the physical activity and the social support levels score were used as an indicator of construct validity, the strategy used in other studies and recommended by previous researches ${ }^{18}$. The Spearman's correlation use is justified by the fact that physical activity data was not normally distributed (Kolmogorov-Smirnov $=0.753, \mathrm{p}=0.001$ ). In this study, the expected result was a positive and significant correlation between the physical activity score and the parents and friends social support scores in light of a consistent relation described between social support and higher levels of physical activity. Social support from parents and friends scores were calculated from the items' responses results sum in each subscale. Physical activity was measured by a previously validated questionnaire for this group ${ }^{26}$. Given a list of 24 physical activities from moderate do vigorous, with the possibility of adding 2 more activities, the adolescents reported the frequency (days / week) and duration (minutes / day) of performed activities in the prior week to the data collection. The physical activity level was determined based on the sum of the products of time by their practice frequency, resulting in a physical activity score in minutes per week.

The sample size was adequate to perform all the study's statistical analyzes. For the CFA, it was assessed that the sample size was appropriate based on three criteria: sample 
must have 500 or more subjects; ratio of $10: 1$ or $20: 1$ between the number of subjects in the sample and the model's free parameters to be estimated ${ }^{20}$. The number of free parameters ranged from 25 (first model) to 100 (multigroups).

\section{RESULTS}

Of the 2,859 who were part of the sample, 104 adolescents who have not responded to one or more items of the physical activity social support scale were excluded. No significant differences (gender, age, economic class, physical activity) among those included and excluded from the analysis $(\mathrm{p}<0.05)$ were identified. The final sample included 2,755 adolescents: $50.2 \%$ female ( $\mathrm{n}=1,586$ ), $53.8 \%$ belonged to $\mathrm{C} / \mathrm{D} / \mathrm{E}$ socioeconomic classes, $82.2 \%$ were $14-17$ years old (average $=16.5 \pm 1.2$ years old) and $50.3 \%$ practiced 300 minutes or more per week of physical activity.

The CFA results supported the hypothesis of a two factors presence for the social support scale: factor 1 - parents' social support, factor 2 - friends' social support, as shown by the model's fit index $\left(\chi^{2}=939.054\right.$; $\mathrm{df}=53$; $\mathrm{p}<0.001$; $\mathrm{RMR}=0.070$; RMSEA $=0.078$ [90\%CI: $0.073-0.082]$; AGFI $=0.912 ;$ GFI $=0.940 ;$ CFI $=0.820 ; \mathrm{NNFI}=0.812$ ).

The model was restructured taking into account the model's fit index, waste values and covariance of the measurement errors between items " $e$ " and " $f$ " for the social support from parents and friends subscale. The new model with the covariance of the measurement errors between items "e" and " $\mathrm{f}$ " for the social support from parents and from friends subscales reached slightly higher levels of fit for some parameters $(\mathrm{CFI}=0.908$, NNFI $=0.905)$, but not all $\left(\chi^{2}=1601.424 ; \mathrm{df}=51 ; \mathrm{p}<0.001 ; \mathrm{RMR}=0.072\right.$; RMSEA $=0.105$ [90\%CI $0.101-$ $0.110]$; AGFI $=0.854$; GFI $=0.905)$, showing that there was no improvement in the model fit compared to the previous one. A third model was built excluding the item "f" ("Parents [friends] talk about physical activity") of each subscale. The exclusion of this item was based on high values in these items waste $(>2.58$ ), in the modified index (parents $\mathrm{MI}=171.636$; $\operatorname{Pr}=0.148$; friends $\mathrm{MI}=160.172 ; \mathrm{Pr}=0.100$ ), the high covariance between the errors in the items " $e$ " and "f " (Parents $=0.497 ; \mathrm{p}<0.01$ and Friends $=0.523 ; \mathrm{p}<0.01$ ), and in the increase in the model's fit index. The model without these two items achieved the best fit indexes $\left(\chi^{2}=897.313 ; \mathrm{df}=34 ; \mathrm{p}<0.001 ; \mathrm{RMR}=0.050 ; \mathrm{RMSEA}=0.063\right.$ [IC90\% $0.060-0.067$; $\mathrm{AGFI}=0.903 ; \mathrm{GFI}=0.940 ; \mathrm{CFI}=0.934 ; \mathrm{NNFI}=0.932)$. It was also identified a reduction in the values of AIC and ECVI when compared to the model with 6 items for each subscale passing, respectively, from 989.054 to 680.531 and from 0.357 to 0.216 . These results were similar in all analyzed subgroups. This model was considered the most appropriate to describe the social support scale, being used in the invariance analysis.

On the social support for physical activity scale with 5 items, all factor loadings were significant and greater than 0.65 (parents: $0.67-0.81$; friends: $0.77-0.87$ ), confirming the factorial validity. Regarding internal consistency, both the subscales of social support from the parents and from the friends reached satisfactory values, $\alpha$ coefficients higher than 0.70 
and negligible variations between the subgroups analyzed (Table 1). The same was observed for the CFI. The final ASAFA Scale version can be seen attached.

To assess the ASAFA scale factorial invariance, it was performed the CFA in each subgroup by adopting a various parameters structured sequence allocation (factor loadings, variance and covariance, measurement errors of the factors items). The results of $\Delta \chi^{2}$ and $\Delta C F I$ indicated the scale's factorial invariance between the various subgroups. The fit indexes achieved satisfactory values and there were overlaps of the confidence intervals of the RMSEA, reinforcing the presence of the scale's factorial invariance (Table 2).

Table 1. Parameters of adjustment quality of models and indicators of internal consistency of the scale of social support for physical activity practice in teenagers. Joao Pessoa, Paraíba, Brazil, 2009.

\begin{tabular}{|c|c|c|c|c|c|c|c|c|c|c|}
\hline \multirow{2}{*}{ Variables } & \multirow{2}{*}{$\chi^{2}(\mathrm{df})$} & \multirow{2}{*}{ p-value } & \multirow{2}{*}{ RMR } & \multirow{2}{*}{ GFI } & \multirow{2}{*}{ AGFI } & \multirow{2}{*}{ NNFI } & \multirow{2}{*}{ CFI } & \multirow{2}{*}{$\begin{array}{l}\text { RMSEA } \\
(90 \% \mathrm{Cl})\end{array}$} & \multicolumn{2}{|c|}{$\begin{array}{c}\text { Internal } \\
\text { consistency }\end{array}$} \\
\hline & & & & & & & & & $\begin{array}{l}\text { ASP } \\
\alpha(\mathrm{CR})\end{array}$ & $\begin{array}{c}\text { ASA } \\
\alpha(\mathrm{CR})\end{array}$ \\
\hline All & $\begin{array}{c}897.313 \\
(34)\end{array}$ & $<0.001$ & 0.050 & 0.940 & 0.903 & 0.932 & 0.934 & $\begin{array}{c}0.063 \\
(0.060-0.067)\end{array}$ & $\begin{array}{c}0.79 \\
(0.84)\end{array}$ & $\begin{array}{l}0.90 \\
(0.92)\end{array}$ \\
\hline \multicolumn{11}{|l|}{ Gender } \\
\hline Male & $\begin{array}{c}300.429 \\
(34)\end{array}$ & $<0.001$ & 0.044 & 0.952 & 0.922 & 0.945 & 0.951 & $\begin{array}{c}0.088 \\
(0.081-0.096)\end{array}$ & $\begin{array}{c}0.78 \\
(0.83)\end{array}$ & $\begin{array}{c}0.90 \\
(0.93)\end{array}$ \\
\hline Female & $\begin{array}{c}646.009 \\
(34)\end{array}$ & $<0.001$ & 0.054 & 0.927 & 0.881 & 0.906 & 0.910 & $\begin{array}{c}0.071 \\
(0.063-0.080)\end{array}$ & $\begin{array}{c}0.79 \\
(0.85)\end{array}$ & $\begin{array}{l}0.87 \\
(0.91)\end{array}$ \\
\hline
\end{tabular}

Age group (years)

\begin{tabular}{|c|c|c|c|c|c|c|c|c|c|c|}
\hline $14-16$ & $\begin{array}{c}631.222 \\
(34)\end{array}$ & $<0.001$ & 0.052 & 0.938 & 0.900 & 0.926 & 0.929 & $\begin{array}{c}0.082 \\
(0.073-0.092)\end{array}$ & $\begin{array}{c}0.79 \\
(0.84)\end{array}$ & $\begin{array}{c}0.89 \\
(0.92)\end{array}$ \\
\hline $17-19$ & $\begin{array}{c}313.168 \\
(34)\end{array}$ & $<0.001$ & 0.051 & 0.935 & 0.895 & 0.933 & 0.940 & $\begin{array}{c}0.081 \\
(0.074-0.088)\end{array}$ & $\begin{array}{l}0.80 \\
(0.85)\end{array}$ & $\begin{array}{c}0.91 \\
(0.93)\end{array}$ \\
\hline
\end{tabular}

Economic class

\begin{tabular}{c|c|c|c|c|c|c|c|c|c|c}
\hline $\mathrm{A} / \mathrm{B}$ & $\begin{array}{c}398.160 \\
(34)\end{array}$ & $<0.001$ & 0.053 & 0.935 & 0.895 & 0.927 & 0.932 & $\begin{array}{c}0.079 \\
(0.071-0.087)\end{array}$ & $\begin{array}{c}0.79 \\
(0.84)\end{array}$ & $\begin{array}{c}0.90 \\
(0.93)\end{array}$ \\
\hline $\mathrm{C} / \mathrm{D} / \mathrm{E}$ & $\begin{array}{c}489.089 \\
(34)\end{array}$ & $<0.001$ & 0.051 & 0.931 & 0.885 & 0.918 & 0.923 & $\begin{array}{c}0.083 \\
(0.075-0.092)\end{array}$ & $\begin{array}{c}0.77 \\
(0.84)\end{array}$ & $\begin{array}{c}0.89 \\
(0.92)\end{array}$ \\
\hline
\end{tabular}

df: degree of freedom; RMR: root mean square residual; GFI: goodness of fit index; AGFI: adjusted goodness of fit index; NNFI: non-normed fit index; CFI: comparative fit index; RMSEA: root mean square of approximation; ASP: parents' social support; ASA: friends social support; CR: composite reliability. 
Table 2. Model fit of the factorial invariance for social support scale for physical activity across different sub-groups (male versus female, 14 - 16 versus 17 - 19 years old, economic classes A/B versus C/D/E). Joao Pessoa, Paraíba, Brazil, 2009.

\begin{tabular}{|c|c|c|c|c|c|c|c|c|c|c|}
\hline Variables & $\chi^{2}(\mathrm{df})$ & $\begin{array}{c}\Delta \chi^{2} \\
(\Delta \mathrm{df})\end{array}$ & $\mathrm{p}$-value & $\triangle \mathrm{CFI}$ & CFI & RMR & NNFI & GFI & AGFI & $\begin{array}{l}\text { RMSEA } \\
(90 \% \mathrm{Cl})\end{array}$ \\
\hline \multicolumn{11}{|l|}{ Gender } \\
\hline $\begin{array}{l}\text { Model } 1 \\
(\mathrm{M} 1)^{*}\end{array}$ & $\begin{array}{c}946.438 \\
(68)\end{array}$ & - & - & - & 0.928 & 0.050 & 0.924 & 0.937 & 0.900 & $\begin{array}{c}0.069 \\
(0.065-0.072)\end{array}$ \\
\hline $\begin{array}{l}\text { Model } 2 \\
(\mathrm{M} 2)\end{array}$ & $\begin{array}{c}959.736 \\
(76)\end{array}$ & $\begin{array}{c}13.598 \\
(12)\end{array}$ & $>0.05$ & 0.000 & 0.928 & 0.051 & 0.922 & 0.936 & 0.908 & $\begin{array}{c}0.065 \\
(0.061-0.069)\end{array}$ \\
\hline $\begin{array}{l}\text { Model } 3 \\
\text { (M3) }\end{array}$ & $\begin{array}{c}964.989 \\
(79)\end{array}$ & $\begin{array}{c}18.551 \\
(11)\end{array}$ & $>0.05$ & 0.000 & 0.928 & 0.054 & 0.922 & 0.936 & 0.911 & $\begin{array}{c}0.065 \\
(0.060-0.067)\end{array}$ \\
\hline $\begin{array}{l}\text { Model } 4 \\
\text { (M4) }\end{array}$ & $\begin{array}{c}977.346 \\
(89)\end{array}$ & $\begin{array}{c}30.908 \\
(21)\end{array}$ & $>0.05$ & 0.008 & 0.920 & 0.055 & 0.913 & 0.929 & 0.912 & $\begin{array}{c}0.063 \\
(0.060-0.066)\end{array}$ \\
\hline \multicolumn{11}{|l|}{ Age group } \\
\hline $\begin{array}{l}\text { Model } 1 \\
(\mathrm{M} 1)^{*}\end{array}$ & $\begin{array}{c}944.390 \\
(68)\end{array}$ & - & - & - & 0.933 & 0.051 & 0.928 & 0.937 & 0.898 & $\begin{array}{c}0.068 \\
(0.065-0.072)\end{array}$ \\
\hline $\begin{array}{l}\text { Model } 2 \\
(\mathrm{M} 2)\end{array}$ & $\begin{array}{c}958.715 \\
(76)\end{array}$ & $\begin{array}{c}14.325 \\
(12)\end{array}$ & $>0.05$ & 0.000 & 0.933 & 0.056 & 0.927 & 0.936 & 0.908 & $\begin{array}{c}0.065 \\
(0.061-0.069)\end{array}$ \\
\hline $\begin{array}{l}\text { Model } 3 \\
\text { (M3) }\end{array}$ & $\begin{array}{c}960.154 \\
(79)\end{array}$ & $\begin{array}{l}15.764 \\
(11)\end{array}$ & $>0.05$ & 0.001 & 0.932 & 0.068 & 0.927 & 0.936 & 0.910 & $\begin{array}{c}0.064 \\
(0.060-0.068)\end{array}$ \\
\hline $\begin{array}{l}\text { Model } 4 \\
\text { (M4) }\end{array}$ & $\begin{array}{c}971.818 \\
(89)\end{array}$ & $\begin{array}{l}27.428 \\
(21)\end{array}$ & $>0.05$ & 0.002 & 0.931 & 0.067 & 0.925 & 0.934 & 0.918 & $\begin{array}{c}0.061 \\
(0.057-0.064)\end{array}$ \\
\hline \multicolumn{11}{|c|}{ Economic class } \\
\hline $\begin{array}{l}\text { Model } 1 \\
(\mathrm{M} 1)^{*}\end{array}$ & $\begin{array}{c}898.098 \\
(68)\end{array}$ & - & - & - & 0.927 & 0.052 & 0.921 & 0.932 & 0.901 & $\begin{array}{c}0.067 \\
(0.063-0.071)\end{array}$ \\
\hline $\begin{array}{l}\text { Model } 2 \\
(\mathrm{M} 2)\end{array}$ & $\begin{array}{c}908.042 \\
(76)\end{array}$ & $\begin{array}{c}9.944 \\
(12)\end{array}$ & $>0.05$ & 0.000 & 0.927 & 0.052 & 0.922 & 0.933 & 0.904 & $\begin{array}{c}0.067 \\
(0.063-0.071)\end{array}$ \\
\hline $\begin{array}{l}\text { Model } 3 \\
\text { (M3) }\end{array}$ & $\begin{array}{c}911.060 \\
(79)\end{array}$ & $\begin{array}{c}12.962 \\
(11)\end{array}$ & $>0.05$ & 0.001 & 0.926 & 0.058 & 0.919 & 0.930 & 0.903 & $\begin{array}{c}0.066 \\
(0.062-0.070)\end{array}$ \\
\hline $\begin{array}{l}\text { Model } 4 \\
\text { (M4) }\end{array}$ & $\begin{array}{c}937.138 \\
(89)\end{array}$ & $\begin{array}{l}39.040 \\
(21)\end{array}$ & $>0.05$ & 0.007 & 0.920 & 0.063 & 0.913 & 0.924 & 0.906 & $\begin{array}{c}0.065 \\
(0.061-0.068)\end{array}$ \\
\hline
\end{tabular}

df: degree of freedom; CFI: comparative fit index; RMR: root mean square residual; NNFI: non-normed fit index; GFI: goodness of fit index; AGFI: adjusted goodness of fit index; RMSEA: root mean square of approximation; M1: configuration model (all parameters are free to be estimated: factor loadings, variances and covariances, error variances); ${ }^{*}$ All other models were compared to model M1, M2: contrasted factor loadings; M3: contrasted variance and covariance; M4: contrasted variance of errors. 
In the Table 3 we can find the correlation coefficients between the duration of physical activity and the social support scores. There were significant positive correlation between the score of physical activity and the social support of parents (rho $=0.28, \mathrm{p}<0.01$ ) and from friends ( $\mathrm{rho}=0.39, \mathrm{p}<0.01$ ), indicating its validity as a construct.

\section{DISCUSSION}

The present study examined the reliability, validity and factorial invariance of a scale for social support for physical activity in teenagers - ASAFA Scale. The results of the study confirmed the presence of two factors for the social support scale, one for measuring social support from parents and the other from friends, showing goodness of fit index and satisfactory internal consistency. Another important finding was the confirmation of factorial invariance, demonstrating that this scale

Table 3. Spearman correlation coefficient between physical activity level and parents and friends social support scores - construct validity - in adolescents. Joao Pessoa, Paraíba, Brazil, 2009.

\begin{tabular}{l|c|c|c|c} 
Variable & Parents' social support & p-value & Friends' social support & $p$-value \\
\hline All & 0.28 & $<0.001$ & 0.39 & $<0.001$ \\
\hline Gender & 0.26 & $<0.001$ & 0.38 & $<0.001$ \\
\hline Male & 0.25 & $<0.001$ & 0.37 & $<0.001$ \\
\hline
\end{tabular}

Age group (years)

\begin{tabular}{l|l|l|l|l}
\hline $14-16$ & 0.27 & $<0.001$ & 0.40 & $<0.001$ \\
\hline $17-19$ & 0.30 & $<0.001$ & 0.39 & $<0.001$ \\
\hline
\end{tabular}

Economic class

\begin{tabular}{l|c|c|c|c}
\hline $\mathrm{A} / \mathrm{B}$ & 0.26 & $<0.01$ & 0.41 & $<0.01$ \\
\hline $\mathrm{C} / \mathrm{D} / \mathrm{E}$ & 0.29 & $<0.01$ & 0.38 & $<0.01$ \\
\hline
\end{tabular}


can equivalently measure social support for physical activity among adolescents of different sociodemographic characteristics. The construct validity was also evidenced by the positive and significant association between the physical activity levels and the score of social support from parents and friends.

One of this study's limitations was to have used a physical activity score produced by the questionnaire as a validation criterion. These measures tend to overestimate the level of physical activity of adolescents ${ }^{27}$. However, the correlation coefficients were in the expected direction and magnitude, resembling those of other studies ${ }^{28,29}$. This study also has its strengths. One of them is to have used a representative sample. Typically, instruments validation studies do not call on representative samples. Have used different analysis procedures to assess the psychometric properties of the scale, especially the evaluation of factorial invariance, was another strong point of this study.

The CFA's results supported this study's hypothesis that assumed the presence of two factors in the social support's scale: (1) social support from parents, (2) social support from friends, confirming the results found in this scale's exploratory analysis ${ }^{19}$. This two factors presence confirmation in the scale of social support assessed in this study is consistent with the proposition that the literature has shown that social support can come from different social groups, especially the support provided by parents and friends ${ }^{12-14}$. It is widely documented that social support from parents and from friends are associated in a particular way with physical activity, indicating that this construct has two distinct dimensions and specific implications for physical activity $^{7,13,14}$. As noted in this study, others also have identified the presence of two factors on social support for physical activity scales, containing items targeted to parents and to friends ${ }^{10,28-30}$. Dishman et al. ${ }^{10}$, when performing the confirmatory factor analysis of a scale of social support for physical activity (with some items similar to this study), also verified the presence of the same factors.

Of the 12 items that were part of the initial scale, we chose to delete the item " $\mathrm{f}$ " ("Parents / friends talk about physical activity") in two subscales or factors. The exclusion of this item was based on high values in these items waste $(>2.58)$, the modification indices - statistical changes magnitude $\chi^{2}$ (parents $\mathrm{MI}=171.636, \operatorname{Pr}=0.148$; friends $\mathrm{MI}=$ $160.172, \operatorname{Pr}=0.100)$ - the high covariance between the errors of the items " $\mathrm{e}$ " and " $\mathrm{f}$ " and the increase in the model's fit indexes22. These findings suggest that the " $\mathrm{e}$ " in each subscale ("parents / friends comment...") and "f" ("parents/friends talk...") measured similar aspects (overlapping content). Another aspect that also reinforced the decision to exclude this item was that the teens reported great difficulty in distinguishing the "comment" from "talk" in the application of this scale in an epidemiological study. It is also important to add that this scale was based on items from other scales, those who used the "comment" not used "talk". Thus, when using these two items in the same scale, it was found that they measured similar aspects. Items with high covariance and waste, when are eliminated of a scale, tend to produce an improvement in model's fit 22. 
High covariance between the scale items errors suggests content overlap, even though described differently22. It is expected that the errors of the items of the same scale are uncorrelated 22 which was not observed in the present study because the correlation between errors of items " $e$ " and " $f$ " were higher among parents subscale ( $r=0.497$, $\mathrm{p}<0.01)$ and friends $(\mathrm{r}=0.523, \mathrm{p}<0.01)$. The factor loadings of these items were the lowest: parent $=0.44$ and friends $=0.59$.

The exclusion of one or more items that do not favor a good model's fit has been recommended and adopted, and should be performed when there are plausibility to support such a decision ${ }^{22}$. Dishman et al. ${ }^{10}$ when analyzed the factorial validity of a scale of social support for physical activity in adolescents with three items for friends and four for parents, excluded one of the items from the scale of the parents for presenting high covariance between two items errors.

The scale of social support for physical activity with five items for each factor showed an increase in their goodness fit compared to the scale with six items. All factor loadings were high $(>0.65)$, significant and saturated in their respective factors: Factor 1 - social support from parents (factor loadings: $0.67-0.81$ ), Factor $2-$ social support from friends (factor loadings: $0.77-0.87$ ). The model's fit indexes reached values within the recommended limits ${ }^{20}$, showing the presence of factorial validity. The factorial validity evidence is important and necessary to define how a set of items measures a construct as defined theoretically ${ }^{20}$.

Regarding internal consistency, it was found that the Cronbach's alpha coefficients $(\alpha)$ values found for the subscale of parental support $(\alpha=0.79)$ and for the friends' support ( $\alpha=0.90$ ) were higher than the minimum value recommended ( $\alpha$ greater than 0.70$)$ to define acceptable internal consistency ${ }^{25}$. The same was observed for the values of the CFI. Other studies also showed similar values to the ones in the present study for the internal consistency of other scales of social support for physical activity practice ${ }^{10,30}$. Kings and Sallis ${ }^{29}$ analyzed the internal consistency of a scale of social support for physical exercise in adolescents in Curitiba and found that the Cronbach's alpha coefficients of internal consistency ranged from 0.69 to 0.83 for the subscale of social support from parents and 0.81 to 0.87 for the social support from friends. Another parameter which reinforces the presence of acceptable internal consistency for the analyzed scale is the magnitude of the item - total correlations (correlation between each item and the overall score of its respective factor). It is recommended that these correlations vary from 0.40 to $0.80^{18}$. In this study, they ranged from 0.50 to 0.68 for the support of parents and from 0.68 to 0.77 for the support of friends (data not shown).

The greater internal consistency identified in the subscale of social support from friends compared to the subscale of social support from parents is explained by the greater amount of time spent together of teenagers with their friends, the peer influence 
on teenagers and the need to commune of certain social norms ${ }^{17}$. Greater impact of social support from friends compared to the parents on adolescent participation in physical activities over the age was reported in several investigations ${ }^{7,12}$.

The social support scale analyzed in this study reported a factorial invariance for the structure and factor loadings, variances and covariances and measurement errors of items among different subgroups (male versus female, $14-16$ versus 17 - 19 years old and economic class A/B versus C/D/E). These results suggest that social support for physical activity practice can be measured equivalently between teenagers of both sexes, age groups and economic classes. Establishing factorial invariance of an instrument allows you to check how much it measures a similar construct among different population subgroups, ruling out that the possible differences between them to be by fluctuations in the psychometric properties of the instrument ${ }^{20,21}$.

The construct validity of the ASAFA scale was observed by the presence of a significant association between the adolescents ' level of physical activity and the score of social support for physical activity practice, as reported in previous studies $^{28,29}$. Significant positive correlations between the level of physical activity and social support scores were identified, reinforcing findings from other studies ${ }^{28,29}$. The social support provided by parents and friends are consistently associated with higher levels of adolescents physical activity practice ${ }^{12-14}$. However, correlations of low to moderate magnitudes were expected, because the practice of physical activity is a complex behavior determined by multiple factors ${ }^{21}$.

The ASAFA scale is the first scale of social support for physical activity practice validated for Brazilian adolescents, considering different types and sources of social support, and ability to assess this construct similarly among adolescents with different sociodemographic characteristics. This is important given that some types of social support are more important than others, depending on the physical activities practiced by the adolescents, and also varying depending on the source of supply of social support (parents versus friends).

However, this scale is more suitable for general physical activities (combining different domains: leisure, commuting, school) or physical activity in the context of leisure. Studies that attempt to assess the influence of social support for physical activity in a given area, for example, active commuting, must resort to scales of social support for this kind of practice, because the types of social support that influence the participation in physical activity vary according to the type of practice. Finally, it is concluded that the ASAFA scale achieved reliability, factorial invariance and satisfactory validity, recommending its use to measure social support for physical activity in teenagers. 


\section{REFERENCES}

1. Hallal PC, Andersen LB, Bull FC, Guthold R, Haskell W, Ekelund U, et al. Global physical activity levels: surveillance progress, pitfalls, and prospects. Lancet 2012; 380(9838): 247-57.

2. Lee IM, Shiroma EJ, Lobelo F, Puska P, Blair SN, Katzmarzyk PT. Effect of physical inactivity on major non-communicable diseases worldwide: an analysis of burden of disease and life expectancy. Lancet 2012; 380(9838): 219-29.

3. Telama R. Tracking of physical activity from childhood to adulthood: a review. Obes Facts 2009; 2(3): 187-95.

4. Van der Horst K, Paw MJCA, Twisk JWR, Van Mechelen W. A brief review on correlates of physical activity and sedentariness in youth. Med Sci Sports Exerc 2007; 39(8): 1241-50.

5. van Sluijs EMF, McMinn AM, Griffin SJ. Effectiveness of interventions to promote physical activity in children and adolescents: systematic review of controlled trials. BMJ 2007; 335(7622): 703.

6. Glanz K, Rimer BK, Viswanath K. Health behavior and health education: health behavior and health education. $4^{\mathrm{a}}$ ed. San Francisco (CA): Jossey-Bass; 2008.

7. Duncan SC, Duncan TE, Strycker LA. Sources and types of social support in youth physical activity. Health Psychol 2005; 24(1): 3-10.

8. Motl RW, Dishman RK, Saunders RP, Dowda M, Pate RR. Perceptions of physical and social environment variables and self-efficacy as correlates of self-reported physical activity among adolescent girls. J Pediatr Psychol 2007; 32(1): 6-12.

9. Lubans DR, Morgan PJ. Social, psychological and behavioural correlates of pedometer step counts in a sample of Australian adolescents. J Sci Med Sport 2009; 12(1): 141-7.

10. Dishman RK, Hales DP, Sallis JF, Saunders RP, Dunn AL, Bedimo-Rung AL, et al. Validity of social-cogntive measures for physical activity in middle-school girls. J Pediatr Psychol 2010; 35(1): 72-88.

11. Taymoori P, Rhodes R, Berry T. Application of a social cognitive model in explaining physical activity in Iranian female adolescents. Health Educ Res 2010; 25(2): 257-67.

12. Dowda M, Dishman RK, Pfeiffer KA, Pate RR. Family support for physical activity in girls from 8th to 12 th grade in South Carolina. Prev Med 2007; 44(2): 153-9.

13. Kirby J, Levin KA, Inchley J. Parental and peer influences on physical activity among scottish adolescents: a longitudinal study. J Phys Act Health 2011; 8(6): 785-93.

14. Morrissey JL, Wenthe PJ, Letuchy EM, Levy SM, Janz KF. Specific types of family support and adolescent non-school physical activity levels. Pediatr Exerc Sci 2012; 24(3): 333-46.

15. Seabra AF, Mendonça DM, Thomis MA, Anjos LA, Maia JA. Determinantes biológicos e sócio-culturais associados à prática de atividade física de adolescentes. Cad Saúde Pública. 2008; 24(4): 721-36.

16. Voorhees CC, Murray D, Welk G, Birnbaum A, Ribisl KM, Johnson CC, et al. The role of peer social network factors and physical activity in adolescent girls. Am J Health Behav 2005; 29(2): 183-90.

17. Plugliese J, Tinsley B. Parental socialization of child and adolescent physical activity: a meta-analysis. J Psychol 2007; 21(3): 331-43.

18. Cook DA, Beckman TJ. Current concepts in validity and reliability for psychometric Instruments: theory and application. Am J Med 2006; 119(2): 166: e7-16.

19. Farias Júnior JC, Lopes AS, Reis RS, Nascimento JV, Borgatto AF, Hallal PC. Development and validation of a questionnaire measuring factors associated with physical activity in adolescents. Rev Bras Saúde Matern Infant 2011; 11(3): 301-12.

20. Kline R. Principles and practice of structural equation modeling. $2^{\text {a }}$ ed. New York: Guild Ford Press; 2005.

21. Vandenberg RJ, Lance CE. A review and synthesis of the measurement invariance literature: suggestions, practices, and recomendations for organizational research. Organ Res Meth 2000; 3(1): 4-70.

22. Byrne BM. Structural equation modeling with AMOS: basic concepts, applications, and programming. Mahwah (NJ): Lawrence Erlbaum Associates Inc; 2010. 416 p.

23. Farias Júnior JC, Lopes AS, Mota J, Santos MP, Ribeiro JC, Hallal PC. Perception of the social and built environment and physical activity among Northeastern Brazil adolescents. Prev Med 2011; 52(2): 114-9.

24. Associação Brasileira de Empresas de Pesquisa (ABEP). Critério de classificação econômica Brasil. Dispinível em http:/ / www.abep.org (Acessado em 26 de novembro de 2009).

25. Helms JE, Henze KT, Sass TL, Mifsud VA. Treating cronbach's alpha reliability coefficients as data in counseling research. Couns Psychol 2006; 34(5): 630-60.

26. Farias Júnior JC, Lopes AS, Mota J, Santos MP, Ribeiro JC, Hallal PC. Validity and reproducibility of a physical activity questionnaire for adolescents: adapting the Self-Administered Physical Activity Checklist. Rev Bras Epidemiol 2012; 15(1): 198-210.

27. Adamo KB, Prince SA, Tricco AC, Connor-Gorber S, Tremblay M. A comparison of indirect versus direct 
measures for assessing physical activity in the pediatric population: a systematic review. Int J Pediatr Obes 2009; 4(1): 2-27.

28. Huang YJ, Wong SH, Salmon J, Hui SS. Reliability and validity of psychossocial and environmental correlates measures of physical activity and screen-based behaviors among Chinese children in Hong Kong. Int J Behav Nutr Phys Act. 2011; 8: 16.

29. Reis RS, Sallis JF. Validade e reprodutibilidade da versão brasileira da escala de suporte social para exercício físico. Rev Bras Ciênc Mov 2005; 13(2): 7-14.

30. Pirasteh A, Hidarnia A, Asghari A, Faghihzadeh S, GhofranipourF. Development and validation of psychosocial determinants measure of physical activity among Iranian adolescent girls. BMC Public Health 2008; 8 :150.

Received on: 08/08/2012

Final version presented on: 10/07/2013

Accepted on: 11/13/2013 
Appendice - Social support scale for physical activity in adolescents - ASAFA Scale Initial version of ASAFA Scale (12 items, 6 items for each kind of social support source)

\begin{tabular}{|c|c|c|c|c|}
\hline \multicolumn{5}{|l|}{ Apoio social dos pais } \\
\hline $\begin{array}{l}\text { Com que frequência durante uma semana típica ou } \\
\text { normal os SEUS PAIS: }\end{array}$ & Nunca & Raramente & Frequentemente & Sempre \\
\hline A. Incentivam você a praticar atividades físicas? & {$\left[\begin{array}{ll}1 & ]\end{array}\right.$} & {$[\quad]$} & [ ] & {[} \\
\hline B. Praticam atividades físicas com você? & [ ] & [ ] & {$[\quad]$} & {[} \\
\hline $\begin{array}{l}\text { C. Transportam ou disponibilizam transporte para você ir } \\
\text { aos locais onde pratica suas atividades físicas? }\end{array}$ & {$\left[\begin{array}{ll}{[} & ]\end{array}\right.$} & {$\left[\begin{array}{ll}{[} & ]\end{array}\right.$} & {$\left[\begin{array}{ll}1 & ]\end{array}\right.$} & {$[\quad]$} \\
\hline D. Assistem você praticando atividades físicas? & {$\left[\begin{array}{ll}1 & ]\end{array}\right.$} & {$\left[\begin{array}{ll}1 & ]\end{array}\right.$} & {$\left[\begin{array}{ll}1 & ]\end{array}\right.$} & {[} \\
\hline $\begin{array}{l}\text { E. Comentam que você está praticando bem suas } \\
\text { atividades físicas? }\end{array}$ & {$[\quad]$} & {$\left[\begin{array}{ll}{[} & ]\end{array}\right.$} & {$\left[\begin{array}{ll}1 & ]\end{array}\right.$} & {$[\quad]$} \\
\hline F. Conversam com você sobre atividade física? & {$\left[\begin{array}{ll}{[} & ]\end{array}\right.$} & {$[\quad]$} & {$[\quad]$} & {[} \\
\hline \multicolumn{5}{|l|}{ Apoio social dos amigos } \\
\hline $\begin{array}{l}\text { Com que frequência durante uma semana típica ou } \\
\text { normal os SEUS AMIGOS: }\end{array}$ & Nunca & Raramente & Frequentemente & Sempre \\
\hline A. Incentivam você a praticar atividades físicas? & {$\left[\begin{array}{ll}{[} & ]\end{array}\right.$} & {$[\quad]$} & [ ] & {[} \\
\hline B. Praticam atividades físicas com você? & {$\left[\begin{array}{ll}1 & 0\end{array}\right.$} & {$\left[\begin{array}{l}1 \\
{[}\end{array}\right.$} & {$\left[\begin{array}{ll}1 & ]\end{array}\right.$} & {[} \\
\hline C. Convidam você para praticar atividades físicas com eles? & {$\left[\begin{array}{ll}{[} & ]\end{array}\right.$} & {$[\quad]$} & {$[\quad]$} & {[} \\
\hline D. Assistem você praticando atividades físicas? & {$\left[\begin{array}{ll}1 & ]\end{array}\right.$} & [ ] & {$[\quad]$} & {[} \\
\hline $\begin{array}{l}\text { E. Comentam que você está praticando bem suas } \\
\text { atividades físicas? }\end{array}$ & {$\left[\begin{array}{ll}{[} & ]\end{array}\right.$} & {$\left[\begin{array}{ll}1 & ]\end{array}\right.$} & {$\left[\begin{array}{ll}{[} & ]\end{array}\right.$} & {[} \\
\hline F. Conversam com você sobre atividade física? & {$[\quad]$} & {$\left[\begin{array}{l}{[} \\
{[}\end{array}\right.$} & {$[\quad]$} & {[} \\
\hline
\end{tabular}

Versão final da Escala ASAFA (10 itens, 5 itens para cada tipo de fonte de apoio social)

\begin{tabular}{|c|c|c|c|c|}
\hline \multicolumn{5}{|l|}{ Apoio social dos pais } \\
\hline $\begin{array}{l}\text { Com que frequência durante uma semana típica ou } \\
\text { normal os SEUS PAIS: }\end{array}$ & Nunca & Raramente & Frequentemente & Sempre \\
\hline A. Incentivam você a praticar atividades físicas? & {$\left[\begin{array}{ll}1 & ]\end{array}\right.$} & {$[\quad]$} & ] & {$\left[\begin{array}{ll}{[} & ]\end{array}\right.$} \\
\hline B. Praticam atividades físicas com você? & {$\left[\begin{array}{ll}1 & ]\end{array}\right.$} & {$\left[\begin{array}{ll}1 & ]\end{array}\right.$} & {$[\quad]$} & {$\left[\begin{array}{ll}1 & ]\end{array}\right.$} \\
\hline $\begin{array}{l}\text { C. Transportam ou disponibilizam transporte para você } \\
\text { ir aos locais onde pratica suas atividades físicas? }\end{array}$ & {$\left[\begin{array}{ll}{[} & ]\end{array}\right.$} & {$\left[\begin{array}{ll}1 & 1\end{array}\right.$} & {$[\quad]$} & {$\left[\begin{array}{ll}{[} & ]\end{array}\right.$} \\
\hline D. Assistem você praticando atividades físicas? & {$\left[\begin{array}{ll}\text { [ } & \text { ] }\end{array}\right.$} & {$\left[\begin{array}{ll}1 & ]\end{array}\right.$} & [ ] & {$\left[\begin{array}{ll}{[} & ]\end{array}\right.$} \\
\hline $\begin{array}{l}\text { E. Comentam que você está praticando bem suas } \\
\text { atividades físicas? }\end{array}$ & {$\left[\begin{array}{ll}{[} & ]\end{array}\right.$} & {$[\quad]$} & {$\left[\begin{array}{ll}1 & ]\end{array}\right.$} & {$\left[\begin{array}{ll}{[} & ]\end{array}\right.$} \\
\hline \multicolumn{5}{|l|}{ Apoio social dos amigos } \\
\hline $\begin{array}{l}\text { Com que frequência durante uma semana típica ou } \\
\text { normal os SEUS AMIGOS: }\end{array}$ & Nunca & Raramente & Frequentemente & Sempre \\
\hline A. Incentivam você a praticar atividades físicas? & {$[\quad]$} & {$[\quad]$} & {$\left[\begin{array}{ll}1 & ]\end{array}\right.$} & {$\left[\begin{array}{ll}{[} & ]\end{array}\right.$} \\
\hline B. Praticam atividades físicas com você? & {$[\quad]$} & {$\left[\begin{array}{ll}{[} & ]\end{array}\right.$} & {$[\quad]$} & {$\left[\begin{array}{ll}{[} & ]\end{array}\right.$} \\
\hline C. Convidam você para praticar atividades físicas com eles? & {$\left[\begin{array}{ll}{[} & ]\end{array}\right.$} & {$\left[\begin{array}{ll}{[} & \end{array}\right]$} & {$\left[\begin{array}{ll}{[} & ]\end{array}\right.$} & {$\left[\begin{array}{ll}{[} & ]\end{array}\right.$} \\
\hline D. Assistem você praticando atividades físicas? & {$\left[\begin{array}{ll}{[} & ]\end{array}\right.$} & {$\left[\begin{array}{ll}1 & ]\end{array}\right.$} & {$[\quad]$} & {$\left[\begin{array}{ll}{[} & ]\end{array}\right.$} \\
\hline $\begin{array}{l}\text { E. Comentam que você está praticando bem suas } \\
\text { atividades físicas? }\end{array}$ & {$\left[\begin{array}{ll}{[} & ]\end{array}\right.$} & {$\left[\begin{array}{ll}1 & 1\end{array}\right.$} & {$\left[\begin{array}{ll}{[} & ]\end{array}\right.$} & {$\left[\begin{array}{ll}{[} & 0\end{array}\right.$} \\
\hline
\end{tabular}

